\title{
SOVIET GENOCIDE AND ITS CONSEQUENCES
}

\section{ARVYDAS ANUŠAUSKAS \\ Genocide and Resistance Research Centre of Lithuania, Vilnius}

Beginning in 1940 Lithuania experienced great cataclysms - the independent state was occupied, its Soviet and Nazi invaders, replacing one another pursued the same policy of annihilating various sections of the population of the country - a policy, which could be defined as genocide. The atrocities of the Nazis, identified and denounced, have been the object of investigation for over 50 years, while the research of Soviet political genocide is only in its initial stage. It is namely the main tendencies, methods and consequences of Soviet genocide that are the subject matter of the present study. Since the definition of the Soviet policy of human annihilation as a genocidal policy is not acceptable to many people, and the Soviet documents relating to the annihilation of ethnic groups are relatively little known, a brief exposition of the term 'Soviet genocide' is given below.

V. I. Lenin, having formulated the main principles of th; existence of the totalitarian Communist state, and dividing society ii " $O$ the rulers and the ruled, attributed exceptional power to the Communist Party. In its turn, the ruling layer was subdiviued into several parts, one of which (the 'ruling classes') had to te eliminated from Communist society. In the ethnic outskirts of the Soviet state such a policy acquired some specific features. Thus, in the case of Lithuania, a partial annihilation or an intentional formation of conditions leading to the destruction of a part of the nation was also to solve more far-reaching social, economic and political changes. It must not be overlooked that ethnic annihilation (the execution of the people based on Communist ideology was called the "suppression of the overthrown classes') was one of the principal tools of Lithuania's Sovietization in the forceful realization of Communist social and economic doctrines. In the opinion of Soviet ideologists, such policy was 'an objective necessity to be implemented in three ways: militarily, economically and politico-legally.

According to international law genocide is an annihilation of entire groups of the population or of its part on racial, ethnic and 
religious grounds. Criminal actions are directed against a particular person, the reason being not any individual peculiarities of that person, but his/her belonging to one of the specified groups of the population. In the 11 November 1946 resolution of the United Nations, the annihilation of a political group is also characterized as genocide. The UN Convention on the Prevention and Punishment of the Crime of Genocide of 9 December 1948, however, does not treat the annihilation of groups of inhabitants on political grounds as genocide. Namely, that was the basis for not treating Soviet terror and its consequences as the crime of genocide. The Soviet annihilation of the people directed against particular ethnic groups was disregarded totally.

In the Lithuanian and Latvian laws the concept of genocide includes the destruction of political groups as well. They are in agreement with the Code approved by the International Law Commission submitted to the General Assembly in 1954. According to that Code inhumane actions of any state authorities or individuals, such as killings, annihilation, enslavement, deportations or persecutions, carried out with respect to any civilians on political, racial, religious or cultural grounds are treated as offences against peace and security of the humankind.

At present, the law of the Republic of Lithuania on the responsibility for the genocide of the Lithuanian population states that the killings and torture of the Lithuanian people and their deportation, committed during the Soviet occupation and annexation of the country, correspond to the norms of international law related to the genocide, aimed at the destruction of a national group. In Lithuania genocidal actions were carried out in the form of unlawful detentions, incarceration, killings and deportations of Lithuanians as a national or ethnic group. People were annihilated not irrespective of their nationality, but as Lithuanians. Soviet genocide was motivated by the necessity of a partial extermination or suppression of the Lithuanians as an ethnic group. Over 70 per cent of the deportees were women and children. As is attested by the documents, in 1949 it was decided in the USSR that 'a child born into a mixed family of a deportee and a non-deportee and having chosen the nationality of the deportee was to be introduced into the lists of the deportees'. ${ }^{1}$ The establishment of a specific legal status of Lithuanian deportees and the fact that a third of them were children show that the annihilation of the Lithuanian population was directed in the first place against ethnic Lithuanians.

${ }^{1}$ GARF, f. 9479 , op. 1, d. 388, 1. 75. 
Genocide was one of the principal methods of Lithuania's Sovietization. The Soviet regime was unique in that its criminal laws were the basis of the crimes it performed and that it endeavoured to partially annihilate (Sovietize) not one or several nations, but all the subjugated nations of the Soviet Union. It was not as 'nationalists', 'kulaks' or people, labelled in some other ways, that then had to go to their doom, but namely as Lithuanians (Latvians, Estonians, etc.). The aspect of nationality, one's belonging to a particular nation, was of decisive importance when intensive Sovietization was being put into practice and a way of its realization - 'suppression' was selected. Lithuania's Sovietization started as soon as an end was put to its independence in 1940. The Lithuanians as well as the other nations (Western Ukrainians, Latvians, Estonians and Poles), subjugated by the Soviet Union as a result of the Nazi-Soviet agreements of 1939, became victims of Sovietization - suppression and sometimes of genocide actions in 1940-1953. Some of the methods, practiced in the actions of terror and genocide (imprisonment in the gulag concentration camps, exile to the North or Siberia), did not mean that the prisoners and deportees had to be exterminated outright (except the period between December 1944 and 1945). However, in the terms of the Convention on Genocide these people were placed in unbearable living conditions, irrespective of the manner of their confinement. The consequences of that tragic situation were a partial or total annihilation of the victims. The Soviet-German war introduced its own correctives into the situation. In 1940-1941 about 30,000 people were arrested and imprisoned or deported; of that number about 23,000 were deported and exiled in 1941. The campaign of terror affected all the nationalities of the country, but it was the Lithuanians that suffered most. The killings that were undertaken in the first days of the war (June 22-28) affected only the Lithuanian civilian population. That was conditioned both by the spread of the armed uprising against the Soviet occupation and by the callous attitude that every former statesman of independent Lithuania or a member of a patriotic organization was an unrelenting enemy of the Communist regime. The killings were conducted not only by the members of the NKVD and NKGB, but also by Soviet activists and Communist Party functionaries. Practically, a score of people were murdered in every district of the country mostly on the basis of the reports of informers or simply on suspicion of allegedly supporting the rebels. Of the total number of 672 killed as many as 518 were killed by the soldiers of the Red Army (these numbers do not include those murdered in Rainiai and in the concentration camp of Pravieniškès, and there are no data, relating to the district of Vilnius). A membership badge from 
a patriotic organization (the Riflemen's Association), if found among somebody's belongings, a hoisted tricolour or white flag, listening to the radio, etc., was good enough reason for a death sentence to be passed. The retreating Red Army killed many local people while ceizing bicycles, horses or clothes. However, the majority of these people were murdered as not loyal enough or actively hostile to Soviet power, according to local Soviet or Party activists. Thus on the 22nd of June fourteen people were tortured to death in the village of Girininkai, rural district of Vainutas, district of Tauragé; five people - in the village of Krušoniai, rural district of Kaišiadorys, district of Trakai; on the 23rd of June - twenty-one persons in the settlement of Kazlų Rūda, district of Marijampolè; on the 23rd-24th of June - fourteen people in the village of Mardosai, rural district of Plungè, district of Telšiai; on the 24th of June - six people (among them five workers of the Aukštoji Panemune TB sanatorium of the Lithuanian Red Cross) in the forest of Pažaislis near Kaunas; etc. Altogether there were nearly 40 group murders. The total number of the civilians, killed on 22-28 June, amounts to 700 (in almost all cases the names of the victims are known), about 400 convicts were killed (half of them are known by name) and about 700 rebels lost their lives (only half of them could be identified). These were the first unprecedented mass murders of Lithuanians in the history of the country. They were usually identified with the activity of local Jewish Communists. Those actions as well as the first mass deportations of 14-18 June 1941 affected the national relations in Lithuania. The increased anti-Semitic layer exploited those events for their anti-Jewish rhetoric.

\section{Punitive Operations and their Victims}

The actions of the physical extermination of the Lithuanian people in 1944-1945 distinguished themselves by their scope, nature and particular brutality. Everything was done under the cover of the struggle against armed anti-Soviet resistance. As the war with Germany was still going on, any resistance in the rear was proclaimed as pro-fascist. At the same time attempts were made to change the attitude of the population of Lithuania (and of the Soviet Union) to the resistance movement. For some time the official propaganda called the organizations of armed resistance 'Lithuanian-German bandit gangs'. Such official directives and propaganda were to camouflage the punitive operations, which eventually developed into genocidal actions. NKVD troops (subordinate to the defence of front rears, and to the frontier, railway and internal troops) started their punitive operations against the members of armed resistance and suspected persons in general in July 1944. Those actions (called military Cheka 
operations) reached a climax in December 1944, when at least sixteen regiments of the NKVD forces were gathered (not taking into account auxiliary troops). ${ }^{2}$

These were the regiments, subordinate to the NKVD, MVD and MGB, that operated in Lithuania in 1944-1953: the 12th, 13th, 25th, 31st, 32nd, 33rd, 34th, 86th, 130th, 132nd, 137th, 216th, 217th, 220th, 261st, 262nd, 266th, 273rd, 285th, 298th, 331st, 338th, and 353 rd infantry regiments, the 23rd, 94th, 95th, 97th and 113th units of frontier troops were the principal performers of punitive operations. Not all the above-mentioned troops were stationed in Lithuania throughout the whole decade; however, the 32nd, 34th, 261st, 298th and 353rd regiments functioned in Lithuania up to 1953 (in August 1951 they were re-named respectively the 4th, 5th, 6th, 7th and 8th units of internal troops). In that period frontier troops also operated in Lithuania; railway protection and escort service regiments were more frequently used in exile operations. In the first years the NKVD concentrated entire divisions for their operations so that several rural districts could be surrounded in one campaign, massive searches conducted, people rounded up and sent to the so-called 'filtration camps'. Those operations were accompanied by unconfined pillage and by the burning of the farmsteads of partisan families or suspected resistance supporters; and sometimes entire villages were burned. In their reports the NKVD soldiers could put down that a barn or a cattle-shed was burned down but not a house; however they always indicated 'killed in an armed engagement'. Killings were carried out in all the districts of Lithuania. In December 1944 as many as 144 farmsteads were burnt down and 265 Lithuanians were burned (shot) as well in ten districts alone. For example, on 17-21 December a battalion of the 13th frontier regiment burned down 46 farmsteads and killed 56 people in the villages of Butkiškès, Vosbutai, Baukiai and Juodaičiai (rural district of Čekiškess, district of Kaunas), and on December 22 burned down nine farmsteads, shot sixteen and burned four people $5 \mathrm{~km}$ to the east of Vilkija in the villages of Bubiai, Ligainiai and Padaugave, among others. ${ }^{3}$

${ }^{2}$ The report of the USSR NKVD and NKGB Commissioner in Lithuania I. Tkachenko of 24 December 1944 to the Chairman of the Lithuanian Bureau of the Central Committee of the All-Union Communist (Bolshevik) Party M. Suslov (here and further cited archival documents are in Russian). Lithuanian Extraordinary Archive [LYA], f.10, b. 4/10, 1. 15-16.

${ }^{3}$ The 20 January 1944 report of the GB Lt. Col. Terent'ev, chief of the operations group of the USSR NKVD and NKGB (the group operated in the district of Kaunas). Ibid., b. 7/27, 1. 33-34;the 23 December 1944 report of the GB Firstrank Commissar Radionov. Ibid., b. 16/6, 1. 85. 
Especially notorious were the murders of the peasants in the rural district of Merkine, district of Alytus. On 24 December, 48 farmsteads were burned there within a radius of several miles. As those farmsteads were far from one another, the details of the killings were not always known. Before setting the buildings on fire the members of the punitive expeditions pillaged them and drove the cattle to Merkine. The men that survived were interrogated, tortured and then taken to Merkinè or Alytus. In the village of Klepočiai 22 people were killed, in Lizdai - ten (two of them - women), in Ryliškiai five, in the villages of Druskininkai, Taručionys, Krikštonys, Pieriškès, Vertelkos - one to three persons in each village. Altogether 48 people were murdered. ${ }^{4}$ In the NKVD documents the recording of the killings of the population had to fit the social political pattern of the occupation and all the documents were kept according to the political requirements of the Communist ideology and a specialized lexicon of the terror system.

Of all the punitive troops the most atrocious was the Fourth division of the internal forces; previously it had distinguished itself in the deportations of the Chechens and other Caucasian nations. In its operations the soldiers of that division alone killed 1,817 people between 13 December 1944 and 31 March 1945: the 25th regiment killed 423 people, the 137th - 335, the 261st - 620, the 298th - 419). Among those murdered by that division there were 550 partisans, while the others were unarmed people, mostly men evading the draft into the Red Army. Later on, the units of the Fourth division also distinguished themselves by their inhuman atrocities. In April-June 1945 the 137th regiment killed 441 people (many of them were burned alive) in the district of Utena alone. ${ }^{5}$ Punitive operations were carried out by other troops as well. On 1-22 January 1945 the NKVD troops of the Lithuanian frontier region (the 23rd, the 95th, the 94th and the 97th frontier detachments) murdered 336 people in the districts of Šiauliai, Panevėžys, Rokiškis, Trakai and Raseiniai; a third of them were killed while 'attempting to hide themselves'. ${ }^{6}$ In the NKVD accounts there appeared a special label for the killed people - 'single bandits'.

${ }^{4}$ The Second Pirčiupis (the manuscript of the memoirs is kept in the author's archive). (In Lithuanian) P. 16, 17, 20. Here some more villages are mentioned those of Bugonys (rural district of Merkinè), Dubriai, Fermos and Vabaliai (rural district of Alovè). At that time no less than 70 farmsteads were burnt. See: Who burned Klepočiai in Pasaulis, (in Lithuanian) 24,1990, 17.

${ }^{5}$ A. Anušauskas. Lietuviutautos sovietinis naikinimas. Vilnius, 1996, 241-241.

${ }^{6}$ Ibid., 234.

${ }^{7}$ The operations report of the Kaunas operational section for June 1 - August 20, 1945. LYA, f. 18, b. 2/62, 1. 98, 104, 107. 
Even the 'Smersh' counter-intelligence departments had to state that 'some [of the officers] kill peaceful civilians in the attempts to camouflage their inactivity in the struggle against banditry'. ${ }^{8}$ The Moscow-appointed governor of Lithuania, head of the Lithuanian bureau of the Central Committee of the All-Union Communist (Bolshevik) Party, M. Suslov, was very confidentially informed that during eight months of 1945 (according to incomplete data) 132 people were 'illegally killed', 41 persons wounded, 167 beaten and 300 families were robbed. ${ }^{9}$ However that was only a small fraction of the victims in the physical extermination of the nation. In 1944-45 according to official data 12,226 people were murdered, of that number 2,056 were killed in December 1944, 1,252 - in January 1945, 1,301 - in February, 1,030 - in March, 1,603 - in April - May 15, 1,135 - in June, 1,436 - in July, 710 - in August, 416 - in September, 238 - in October, 249 - in November and 315 - in December. ${ }^{10}$ In 1944 only about a tenth of those people lost their lives in the armed resistance movement fighting for the independence of Lithuania; of these nine-tenths were unarmed civilians, who were killed, tortured to death or burned alive.

Analysis of the NKVD operation reports reveals that in 1945 no less than 3,000 murdered unarmed civilians were registered as killed partisans (in January - March the Fourth infantry division killed about 900 unarmed people; from 28 March to 18 May a joint frontier detachment killed about 270 civilians; on January 1-22 other frontier guards killed about 110 people, etc. Altogether about 5000 murdered unarmed people were entered in the records among the names of the killed partisans in 1944-1945. Those who were not killed outright, but were suspected as supporters of the armed Lithuanian resistance, or saboteurs trying to disrupt government orders (there were scores of reasons for arrest and imprisonment) were taken into custody or

${ }^{8}$ The report of the 'Smersh' counter-intelligence department of the NKVD. Archive of the Ministry of Internal Affairs (VRMA), f. 18, ap. 1, b. 7, 1. 25.

${ }^{9}$ The report on the violations of the NKVD troops and NKGB. Research Centre of Modern Russian History, (ICNRI) f. 597, op. 1, d. 17, 1. 125.

${ }^{10}$ The December 241944 report of the USSR NKVD and NKGB Commissioner in Lithuania I. Tkachenko to M. Suslov. LYA, f. 10, b. 4/10, t. 1, 1. 15-22; Five-day and monthly reports of J. Bartašiūnas and A. Guzevičius to L. Beriya and V. Merkulov. Ibid., f. 3, b. 7/120, 1. 131; b. 7/111, 1. 334-336; f. 10, b. $4 / 10$, t. 1, 1. 34-36, 66-68, 134-136, 163-166, 188-190; five-day accounts of the LSSR NKVD and NKGB for 20 July 1945 - 1 January 1946, f. 10, b. 3/7, 1. 113, 281 , 411; b. 2/29, 1. 155, 172, 186, 194, 207, 210, 218, 228, 236, 245, 260, 267, $274,279,286,292,299,308,315,322,337,345,351,355,362,367$. 
sent to numerous NKVD prisons. All the people, who were seized by the NKVD (MVD) or NKGB (MGB, KGB), at first were treated as 'detainees' and later after certain formalities (after issuing a backdated arrest warrant) they became 'arrested'. Both the detainees and the arrested were imprisoned and interrogated in the same conditions. However few documents are extant showing how many people were kept in NKVD or NKGB headquarters basements - 'internal prisons'. The available documents present contradictory data, not sufficient and not reliable enough.

Nevertheless, a comprehensive analysis of the accessible sources and additional calculations reveal a preliminary picture of the damage done to the population of Lithuania.

Table 1

The Consequences of the 1944-1945 Terror and Genocide Actions*

\begin{tabular}{|c|c|c|c|}
\hline & 1944 & 1945 & Total \\
\hline $\begin{array}{l}\text { Those who: } \\
\text { a) were detained } \\
\text { b) turned up for legalization } \\
\text { Of those who were detained } \\
\text { or turned up for legalization were: } \\
\text { a) conscripted into the Red Army } \\
\text { b) sent to filtration camps } \\
\text { c) legalized } \\
\text { d) arrested } \\
\text { Of those arrested: } \\
\text { a) were set fre }{ }^{\mathrm{a}} \\
\text { b) were sent to gulags } \\
\text { c) died, were tortured to death in prisons }{ }^{\mathrm{a}} \\
\text { d) were sentenced to death } \\
\text { e) were kept in Lithuanian prisons } \\
\text { (1945 } 1201 \text { ) } \\
\text { f) were handed over to conscription offices } \\
\text { Were killed or perished in partisan fights }\end{array}$ & $\begin{array}{c}24,100 \\
285 \\
13,167 \\
680 \\
1,338\end{array}$ & $\begin{array}{c}22,574 \\
6,533 \\
35,859 \\
41,000 \\
\\
6,740 \\
31,323 \\
468\end{array}$ & $\begin{array}{c}7,420 \\
32,661^{d} \\
490 \\
721 \\
9,801 \\
\\
1,338 \\
12,266\end{array}$ \\
\hline
\end{tabular}

${ }^{a}$ Prior to December 1, 1945.

${ }^{\prime}$ Including the number (about 2,000) of those arrested by the NKVD in November - December and by NKGB in December, 1945.

${ }^{\prime}$ Only the Poles are taken into consideration; see J. Bartašiūnas undated report to A. Leontyev, LYA, f. 3, b. 20/163, t. 2, l. 174.

*The table was prepared on the basis of (1) Lt. Col. B. Burylin's information of November 1945 about the NKVD struggle with armed resistance, LYA, $f .3$, b. 41/131, l. 5-6; (2) the NKVD and NKGB information of December 1945, ibid., l. 11-12; (3) the author's estimates. 
dThe numbers of those sent to the gulags were established according to these documents: (1) an unsigned report of December 24, 1945 of the Prison Department of the NKVD of the LSSR, ibid., (2) Col. Burylin's report of November 1945 and Lt. Col. Kharchenko's report of November 30, 1945, ibid., 6, 16; (3) Summary reports of prisoner statistics, State Archive of the Russian Federation (GARF), f. 9413, op. 1, d. 631 (the number of those deported by 'Smersh' is not known).

'See: Data of prisoner statistics (January 1, 1945),ibid., b. 63, l. 3-4; M. Suslov's report of 1946 to G. Malenkov, ICNRI, f. 597, op. 1, d. 24, l. 8; the data of 1945 deal only with those, sentenced by the military tribunals of the NKVD under article 58; later on the sentences were commuted.

The suppression of any Lithuanian aspirations to restore their independent state was a necessary prerequisite for the Sovietization of the occupied country. When the early attempts to break down the anti-Soviet resistance failed, the organizers of the physical extermination of the Lithuanian nation had to resort to new techniques in the autumn of 1945. Large-scale actions, in which scores and hundreds of unarmed people were annihilated, were given up - militarily they did not do any direct harm to the resistance movement. A dense network of permanent NKVD garrisons was organized throughout the country. Mobile detachments, which had operated in various places of the country in 1944-1945, were replaced by garrisons of approximately 150 men in 165 towns and settlements in 1946. Their frequent raids and occasional joint punitive actions of hundreds and even thousands of soldiers of mobile units had to crush the armed resistance of the country. Despite the frantic efforts of Lithuanian freedom fighters not a single locality managed to avoid the fatal consequences of those atrocities. In 1944-1949 as many as 1,554 people were killed or perished in the resistance battles in the district of Alytus (in the pre-war administrative boundaries), in Panevėžys - 1,544, in Utena - 1,431, in Ukmergè - 1,379, in Trakai - 931, in Rokiškis 905, in Marijampolè - 888, in Biržai - 870, in Kaunas - 808, in Šiauliai - 797, in Švenčionys - 569, in Kèdainiai - 547, in Raseiniai - 472, in Lazdijai - 394, in Telšiai - 383, in Vilnius - 357, in Šakiai - 321, in Zarasai - 319, in Kretinga - 259, in Mažeikiai - 182, in Vilkaviškis 110, in Klaipèda - 33, in Šilutè - 13, in Pagègiai - 5 (the data of 1946 and of June-December 1948 are excluded from the indicated numbers related to the districts). ${ }^{11}$ Taken all in all, these data lead to the

${ }^{11}$ This count covers only 75 per cent of all the victims or 16,107 persons. These estimates were carried out by the author taking into account the pre-war 
conclusion that in 1944-1953 punitive military operations, conducted by the NKVD (MVD) and MGB were the principal ways of the suppression of the resistance of the Lithuanian population, no matter whether they were performed by divisions, regiments, companies, commandos or separate Cheka groups. The MVD and MBG and their troops were the main agents in all the genocide actions (arrests, deportations, etc.) in the country.

\section{Gulag Confinement}

The Sovietization of Lithuania and the suppression of its resistance would hardly have succeeded but for mass arrests. Every other male Lithuanian was either a victim of oppression or passed through the 'filters' of the terror system. It must be stressed that the aims of the arrests and the terror, into which the country was plunged, were more far reaching than the mere suppression of resistance. The complete subjection and Sovietization of Lithuania, establishing Soviet control over all areas of life and reconstruction of the society according to the communist ideological postulates could not have been accomplished without violence and terror - without the annihilation of that layer of Lithuanian society, which was most prominent in social, political and economic activity of the country. In the period between 1944 and 1945 alone over 200,000 people in one way or another experienced reprisals of the occupying forces (imprisonment, recruitment to the Red Army, persecution, etc.). Of that number about 54,000 were sentenced to longer terms of imprisonment and 32,661 were sent to the gulags. In both cases years, spent in confinement, were ruinous to both physical and mental health of the detainees.

The conditions in the general and internal prisons of the NKVD (MVD) and MGB were appalling In order to conceal the fact of the torture of the imprisoned people the basements of the NKVD (MVD) and MGB premises were converted into internal prisons. Their cold, damp cells were crammed with people. Depending on the results of punitive operations the number of inmates in regional general prisons varied. Three, six, nine or even thirteen people could be incarcerated in a place normally intended for one person. By worsening the conditions of imprisonment the jailers sought to impair the physical and mental health and to break the spirit of the prisoners. The conditions in the NKVD and NKGB prisons in Lithuania, where

administrative division of the country on the basis of the following documents: $\mathrm{Cpt}$. Shcherbakov's report of June 1946, LYA, f. 6, b. 41/131, 1. 67; Maj. Figurin's report of 30 March 1948, ibid., b. 41/135, t. 1, 1. 138-139, Maj. Shcherbakov's report of 30 January 1950, ibid., b. 41/140, 1. 111-112. 
prisoners were kept for long terms, were more terrible than those in other prisons of the USSR. On 1 July 1945, of the total number of 10,760 prisoners, kept only in general prisons (those in internal prisons and in district detention centres are not included), 1,909 people were incarcerated for at least four months and 1,156 - for between two and four months. ${ }^{12}$ As many as 21 to 31 per cent of all the inmates were ill with various diseases - tuberculosis, pneumonia, typhus, scurvy, etc. ${ }^{13}$ In $1945,6,834$ prisoners ${ }^{14}$ died in all the prisons of the USSR, while in Lithuania the number of deaths was 490. Epidemics, mental diseases, suicides were quite common. In 1944-1945 and in 1948-1952 the number of the LSSR NKVD (MVD) and MGB victims was 718 in general prisons. ${ }^{15}$ The dead person's relatives received a death certificate, in which, however, the burial place was not indicated.

A number of those sentenced were kept in Lithuania, where a gulag branch was established with several camps and colonies:

Section no. 1 of Vilnius camp, consisting of three posts (LP in Russian lagernyi punkt, lit. camp post) - LP-1 - Rasos camp , LP-2 - a women's camp in Danilevičiaus and Gudų Str., 'Liubovo LP' - an agricultural camp in Riešé; Pravieniškés camp (camp section no. 2); Šilutè (Macikai) camp (camp section no. 3) and Rusnè LP-5; correctional labour colonies of Klaipeda and Akmene (nos. 4 and 9), the distribution prison of Vilnius (a centre were prisoners were gathered for the distribution and transportation to the gulags) and a prison hospital. These camps and colonies were set up in Lithuania in 19441951. Officially they were destined for criminal offenders, however, it is evident that people sentenced for 'counter-revolutionary offences' were also kept there. The number of ordinary criminal offenders (recidivists) was only $287,{ }^{16}$ all the others were sentenced for the

${ }^{12}$ Lietuvos Visuomenès Organizacijų Archyvas [LVOA] (Archive of Lithuanian Social Organizations), f. 1771, ap. 8, b. 179, 1. 124.

${ }^{13}$ The 1941-1945 summaries of prisoner sickness and mortality rate, drawn up by M. Nikolsky, head of the Prison Board of the USSR NKVD. GARF, f. 9413, op. 1, d. $73,1.55,100$.

${ }^{14}$ The May 17, 1946 report of Col. of medical service Dostovalov, head of the sanitary office of the NKVD Department of Prisons. Ibid., d. 73, 1. 130.

${ }^{15}$ According to the MVD documents the average prisoner mortality was 0.5 per cent in Lithuania in 1948. That means that in 1946-1947 about 200 could have died from the total number of prisoners of about 40.000 . This number would be an inference, since there are no supporting documents. In the LYA there are 765 cases of dead prisoners (inquiry was dropped).

${ }^{16}$ The 1 July 1952 report of the Forced-Labour Camps Department of the LSSR MVD. GARF, f. 9414, op. 1, d. 415, 1. 27; on 1 July 1952, 1,833 people, 
so-called minor crimes, failure to pay governmental taxes or to supply requisitioned quotas of agricultural produce. The number of female prisoners was quite significant - 2,026 (the data of April 1, 1952). ${ }^{17}$

The Šiluté camp was exceptional in certain respects. In 19461952 between 1,000 and 3,000 prisoners were kept in it. Since hundreds of women were incarcerated there (on 1 April 1952, there were 1,086 of them), the camp had a special section for children - imprisoned or born there. On 16 July 1952, in a building, adapted for one hundred small inmates, there were 156 children. Between 1949 and 1952 there were 620 children (194 of them were born there) ${ }^{18}$ with their imprisoned mothers in the camp. Their names also figured in the lists of the camp victims. Extant data on dead prisoners cover only the period between 1948 and 1955: from the total number of 365 dead prisoners 312 were Lithuanians ( 85 per cent). Of that number 37 persons were sentenced under Article 58 of the Soviet Penal Code, 153 - under the Decree of 7 April 1948 and 166 - under the Decree of 4 June 1947. Among those who lost their lives 119 had reached the age between 60 and 82 . Among the 70 dead children of the camp 44 were Lithuanian (62 per cent). ${ }^{19}$ Many more dead prisoners were buried in the cemetery of the camp.

Prisoners' health seriously deteriorated in the process of interrogations, as extreme torture was sanctioned. In 1937 the Central Committee of the All-Union Communist (Bolshevik) Party officially approved the use of 'physical coercion'. On 10-20 January 1939, the same institution again sanctioned 'physical coercion as an exceptional means to be practiced in future as well in respect to evident stubborn enemies of the people as a fully justified and expedient method' ${ }^{20}$ The use of torture in interrogations was classified as secret, therefore no documents relating to it can be found. Nevertheless some indirect evidence has been preserved. Officially tortures were referred to as 'measures of physical coercion', 'active interrogation', etc.

sentenced to three years of detention, were kept in the camps and colonies of Lithuania; 1,218 - to five years and 2,800 - to ten years of detention.

${ }^{17}$ Additionally, there were 58 teenagers.

${ }^{18}$ The 1949-1952 registration journal of the children, born in the Šilute camp.

VRMA, f. 11, ap. 2, b. 12, 1. 1.

${ }^{19}$ According to the author's estimates no less than 559 people perished in the camp.

${ }^{20} \mathrm{O}$. Suvenirov. Narkomat oborony i NKVD v predvoennye gody (People's Commissariat of Defence and NKVD in pre-war years). Voprosy istorii, 6, 1991, 32. 
Although torture was a commonplace interrogation method in the work of the NKVD, NKGB and counter-intelligence 'Smersh', rare were the cases, when its use came to light. There were the socalled sanctioned and unsanctioned tortures. Sanctioned torture was approved by the chiefs of the MVD or MGB, and unsanctioned one was carried out without the official permission, there being no direct need for its application. It was used when a person was detained officially, his/her interrogation was not urgent and the information obtained was of no great value in fighting resistance. Unsanctioned torture, the result of which was insignificant information, was treated by the chiefs of MVD and MGB as inefficient work. On 8 March 1951 even the military procurator of the MVD S. Grimovich had to admit that '...many statements of those who 'acknowledged their guilt' ... were obtained after adopting measures of physical coercion'. ${ }^{21}$ Tortures according to the instructions of the USSR MVD and MGB were used extensively while interrogating people, accused of 'treason', i.e., active or passive resistance to the occupational powers. That means that in the first place namely political prisoners were mutilated during the interrogations, carried out in Lithuania. In 19441952 the number of such people was no less than 62,086 (those deported from Lithuania in 1945 are not included), among them 45,429 members of resistance and their supporters. ${ }^{22}$

Since from the 200,000 detainees 29,726 persons were set free, no action being brought against them after a shorter or longer period of interrogation, ${ }^{23}$ it could be surmised that the rest either perished or their health was injured to a certain extent, especially if afterwards they were taken into gulags.

In 1940-1941 and 1944-1952 the number of the deported prisoners from Lithuania was nearly 150,000. In 1945-1952 there were 54 'transports', in each of which 1,000 and more detainees, kept in Lithuanian prisons, were deported. Among those sent to the gulags there were persons against whom no actions were brought. They were peasants, arrested during military punitive operations as suspected supporters of the resistance movement. Sooner or later these people were sentenced to 10 to 25 years of gulag imprisonment by NKVD courts.

Gulag camps were not just ordinary detention centres. There people had to experience lots of physical and moral traumas. The

${ }^{21}$ LVOA, f. 1771, ap. 108, 1. 194.

${ }^{22}$ The December 1952 report of Maj. Gen. P. Kondakov. LYA, f. 3, b. $56 /$ 28, 1. 264-265.

${ }^{23}$ The 1945-1952 prisoner summaries of the USSR MVD prisons. GARF, $f$. 9413 , op. 1 , d. 63 , 1. 3-284; d. 90 , 1. 1-185; d. 100, 1. 1-188;.d. 118, 1. 1-327. 
number of prisoners in the camps varied, depending on hard work, hunger and diseases, leading to increased mortality. In gulag documents this kind of extermination of human beings was referred to as (a) 'strengthening the isolation of prisoners and the struggle against anti-Soviet manifestations; (b) preserving the physical fitness of prisoners and ensuring their full continuous employment' ${ }^{24}$

The results of the physical annihilation of prisoners became conspicuous already in 1942. The 1940 estimation of the NKVD showed that 35.6 per cent of the inmates were suitable for hard labour, 25.2 - for less hard, 15.6 - for easy work and 23.6 per cent were disabled. In 1942 the distribution percentage of the same categories was as follows: $19.2,17.0,38.2$ and 25,5 per cent. ${ }^{25}$ Of the Lithuanians, deported to the gulags in 1941, as many as 85 per cent were dead by the year 1945 .

In the words of a former deportee and prisoner, 'the aim of Soviet gulags was to turn a human being into a slave, submissive and obedient to strong and weak power, incapable of thinking, of resisting violence and tyranny'. ${ }^{26}$ Those who refused to submit were subjected to various forms of repression - solitary detention, ${ }^{27}$ barracks of hard discipline (the so-called 'burs' -baraki usilennogo rezhima Rus.), ${ }^{28}$ or to additional sentences, passed by gulag courts. Emaciated prisoners were checked by 'a medical commission' to determine their capacity for work. 'A line of naked cadaverous creatures slowly moved past such a commission, whose members determined whether the prisoner was able to work by pinching the tissues of the buttocks: if there was still some flesh there, the inmate was considered 'trudosposoben' (Rus. fit to work)', remembers B. Balaika, a former prisoner of a Norilsk gulag. ${ }^{29}$ All the gulag prisoners had to

${ }^{24}$ The 17 August 171944 report of the GB Third-rank Commissar Nasedkin about the gulag activity in 1941-1944, ibid., f. 9414, op. 1, d. 68, 1. 2.

${ }^{25}$ Ibid., 16.

${ }^{26}$ A. Šerenas. Atsiminimai (Reminiscences), t. 3, 1. 23

${ }^{27}$ Prisoners were kept in solitary confinement for several days, rarely for a longer period, for minor offences (in the opinion of the jailers and guards). That was one more kind of torture, those detention places being most varied - pits with water, structures without roofs, etc. Such detainees were not taken to work.

${ }^{28}$ 'Burs' were intended for those who refused to go to work or had made attempts to escape from the camp and also for those prisoners who were interrogated It was a real gulag prison where inmates were kept for months and forced to go to work (in some gulags those kept in the 'burs' were not taken to work). Ibid., 1. 24; K. Lakickas. Kalinys Z-311 (Prisoner Z-311). Vilnius, 1994, 160-161; B. Antanaitis. žodžiai iš pragaro (Words from Hell). Vilnius, 1991, 115.

${ }^{29} \mathrm{~B}$. Balaika. Vieną poliarinę dieną (On one polar day). Tremtinys, 16, 1991. 
do the work for the fulfilment of which the gulag itself was set up in an appropriate locality. In 1948 special new gulags were established in order to use political prisoners (officially referred to as 'particularly dangerous state criminals') for the most difficult work and to strengthen the discipline of imprisonment. As was mentioned above, in 1944-1953 over 80,000 political prisoners were sent to gulags from Lithuania. Not all of them were placed in the special camps, but many of them were their inmates. On 1 January 1952, of the 258,323 prisoners of the special camps there were as many as 22,636 Lithuanians. ${ }^{30}$ That means that in 1948-1954 as many as half of the Lithuanian prisoners were incarcerated in the special gulags, in which living and working conditions were most appalling. The fact that among the prisoners of these gulags Lithuanians occupied the third and sometimes even the second place (e.g., in Steplag) in terms of numbers (a tenth of all the prisoners) is indicative of certain trends of the atrocity: the Lithuanians - former government ministers, civil servants, policemen, etc. of independent Lithuania and members of the antiSoviet resistance movement were never to come back to their homeland.

The prisoners were required to do the most difficult underground jobs in coal and uranium mines, on tree-felling sites and other activities demanding hard manual labour. E.g., in the Rechnoy camp (in Vorkuta, Komi ASSR) prisoners (in 1952 Lithuanians made up 12.2 per cent of them) worked in seven mines, ${ }^{31}$ in the Stepnoy camp (Karaganda oblast, Kazakh SSR) they built ore-processing, brick manufacturing, reinforced concrete and other factories. ${ }^{32}$ On the average 1.2 per cent of the prisoners lost their lives each year in these special camps. ${ }^{33}$

Table 2

Changes in the Number of Prisoners in 1951

\begin{tabular}{|l|c|c|c|c|}
\hline & 1951 & & & 1952 \\
\hline & January 1 & July 1 & October 1 & January 1 \\
\hline In camps & 35,777 & 36,696 & 37,476 & 40,124 \\
In colonies & 7,243 & 6,737 & 6,809 & 6,936 \\
Total & 43,020 & 43,433 & 44,285 & 47,124 \\
\hline
\end{tabular}

The data for the Table are taken from RFVA, f.9414, op. 1, d. 1356, l. 4, 78, 110, 139.

${ }^{30}$ The number of prisoners in MVD colonies and camps. GARF, f. 9414, op. 1, d. 1356, 1. 21, 64, 155-160; d. 1385, 1. 1-11.

${ }^{31}$ A. Šerènas. Ibid., t. 3, p. 226.

${ }^{32}$ Vosstanie v Steplage (Rebellion in Steplag). Otechestvennye arkhivy, 4, 1994, p. 42-44, 50-51, 55.

${ }^{33}$ Statistical data of December 1952 about particularly dangerous state prisoners, held in special MVD camps. GARF, f. 9414, op. 1, d. 1385, 1. 1-11. 
Thus far no data have been found concerning the mortality of Lithuanian prisoners. According to the documentarily attested mortality rate, it can be surmised that no less than 20-25 per cent of all those deported to the gulags died in 1940-1956; in other words, every third political prisoner perished, since many of them were incarcerated in 1941-1944 - the period of the highest mortality rate (in some camps nearly two-thirds of all Lithuanian prisoners died) - and afterwards they also were kept in the most gruesome conditions; thus the total number would be about 30,000-40,000 people (among them - 20,000-25,000 political prisoners). By 1958 about 19,000 of those who had been imprisoned for 'particularly dangerous offences', i.e., as political prisoners, returned to Lithuania. Some scores of thousands of former political prisoners were either missing or for a long time were not allowed to go back to Lithuania. Thus numerous demographic, social, moral and other consequences, crucial for the future existence of the Lithuanian nation, were predestined by the Soviet gulag policy.

\section{Deportation: Destruction of Families}

Deportation as a genocide method, practiced by the Soviets, has been most closely examined. Deportations, treated according to the Convention on Genocide as a conscious action, leading to a partial or total extermination of the population, were sanctioned by the highest officials of the Soviet power. In the course of time their motivation changed. In some periods the ethnic principle replaced the dominating political, the latter could overshadow the former, etc.

In 1992-1996 the numbers of the deportees were defined more accurately and the lists of those deported in 1941-1953 were drawn up. It has been established that from the 155,796 persons, ${ }^{34}$ selected for deportation by the organizers of Soviet genocide, no less than 132,000 were exiled to Buryat-Mongolia, Komi, the territories of Krasnoiarsk, the oblasts of Irkutsk, Tomsk, Molotov (now - Perm) and other Siberian and Northern regions (the indicated number is far from exact, taking into account the inaccuracies of the documents; it is noteworthy that when the lists were compiled by names, the number of the deportees of 1940 rose from 12,562 to 14,381 - by 14.5 per cent). In 1946-1952 the number of deportees in the Soviet Union was 676,835 persons, in the MVD and MGB documents referred to as 'specially displaced persons'. Nearly every sixth of them was a Lithuanian, in some years the Lithuanians made up a half of all the deportees of the Soviet Union.

${ }^{34}$ E. Grunskis. Lietuvos gyventoju tremimai 1940-1941, 1945-1953 metais. 


\section{Table 3}

The Percentage of Lithuanian Deportees among the Deportees of the USSR**

\begin{tabular}{|c|c|c|c|}
\hline $\begin{array}{c}\text { Total number of deportees in the } \\
\text { USSR }\end{array}$ & \multicolumn{2}{c|}{$\begin{array}{c}\text { Number and percentage of } \\
\text { deportees from Lithuania }\end{array}$} \\
\hline $1946-1947$ & 255,198 & $8,402^{\mathrm{a}}$ & $3.2 \%$ \\
1948 & 89,261 & 43,940 & $49.2 \%$ \\
1949 & 221,231 & $33,500^{\mathrm{b}}$ & $15.1 \%$ \\
1950 & $43,063^{\mathrm{c}}$ & 1,355 & $3.0 \%$ \\
1951 & $45,483^{\mathrm{d}}$ & 21,177 & $46.5 \%$ \\
1952 & $22,599^{\mathrm{e}}$ & 2,934 & $13.0 \%$ \\
\hline Total & 676,835 & 111,308 & $16.4 \%$ \\
\hline
\end{tabular}

${ }^{a}$ This number does not include the deportees of December 1947 - in the $M V D$ and MGB documents they are usually attributed to the deportees of 1948. Neither are included the Germans, deported in 1945.

${ }^{b}$ See: E. Grunskis. Lietuvos gyventoju deportacijos, 1941-1952 metu Lietuvos tremtiniai. Vilnius, 1, 1993, 18.

${ }^{c}$ This number did not at all include Lithuanian deportees.

${ }^{d}$ There is one more number in the document - 33,979. GAFF, f. 9479, op. 1, d. 641, l. 282.

${ }^{e}$ This number comprises only 2,195 Lithuanians, exiled in January 1952. Ibid., 284.

The seizures of people for deportations could be accompanied by deaths, as any attempt to escape or resist arrest was ruthlessly suppressed. Those who tried to flee, were shot at and, if caught, were brutally beaten. The numbers of deaths were conditioned not only by the way the round-ups and arrests were carried out and by the circumstances of deportation when people were crammed into cattletrucks and transported in unimaginably appalling conditions. The mortality of the deportees also depended on the fact that the majority of them were women and children - over 70 per cent. In 1941-1953 no less than 39,000 children and 50,000 women were dispatched to distant regions of the USSR. In addition to very young, those who died in the first place were old people, pregnant women and babies born en route; the latter, if they did not reach the place of destination, were even not registered. In 1948 alone according to the MGB information during the transportation of 30,888 deportees (77.2 per cent of all those deported in the great exile) 198 persons ( 0.64 per cent) did not arrive at the place of destination (some were wounded

**The Table is based on Maj. Turov's report of 29 April 1953. GARF, f. 9479, op. 1 , d. $641,1.270$. The data about the deportation of 1945 are not available. 
in the journey) - 47 of them died, while 104 were left at wayside hospitals. ${ }^{35}$ No less than 50 people (including many babies) died during the deportation of March 1949. In the October 1951 deportation 39 children died. ${ }^{36}$ Annihilation of the deportees continued in the gulags. By 1945 a half of the first deportees (among whom there were many Poles and Jews) had died. After 1945 the national variety of the deportees disappeared. After the war only Lithuanians and people in some way associated with them were subjected to deportation. In 1945-1947 about 40 per cent of the total number of deportees died, in 1948 - 4 per cent, in 1949 - 3 per cent, in 1950 - 2 per cent, in 1951-1952 - 1.2 per cent, in 1953-1955 - 1 per cent and in 19561957 - 0.85 per cent. Doubtless these figures are relative, they are also dependent on the place of the exile. For example, in Tajikistan 80 percent of all deportees died. The mortality rate of Lithuanian deportees was higher than that of other nationalities: of 11.479 dead in January-March 1949 the number of Lithuanians was 482 (4.2 per cent), i.e., it was three times higher than among the Ukrainians and even 13 times higher than among the Poles, kept in Kazakhstan. ${ }^{37}$

It is difficult to establish accurate figures of those who died in the most appalling exile conditions. MVD reports are full of contradictory numbers, especially prior to 1949 . There are no statistics related to the years 1945-1947, July-December 1948, October 1949$1951,1953,1955$ and 1958. Incomplete are the data of January-June 1948, January-September 1949, January-June 1952, 1954, 1956 and 1957. The special MVD headquarters used to count only the deaths of those related to labour force; dead children were not always taken into account. On the basis of the MVD and MGB documents, it is possible to establish that by 1 January 195398,286 had survived from 118,000, deported in 1945-1952. Thus, the number of deportees decreased by $20,000 .{ }^{38}$ Several hundred deportees (relatives of

${ }^{35} \mathrm{Jr}$. Lieut. Bolotnikov's report of 2 July 1948 about the formation and departure of transports. GARF, f. 9479, op. 1, d. 427, 1.69-73; Maj. Mordvinenko's report of September, 1948, ibid., 161. The final figures were obtained comparing the published materials in Lietuvos gyventoju trémimai . Vilnius, 1995, p. 422-426, 440-441, documents no. 106 and 109.

${ }^{36}$ Maj. Turov's report of 29 April 1954 about the number of deportees and its dynamics. GARF, f. 9479, d. 641, 1. 282.

${ }^{37}$ The report of the first quarter of 1949 about the number of prisoners and its dynamics. Ibid., d. 488, 1. 39.

${ }^{38}$ This is supported by MVD documents. E.g., in 1945-1948 there were 49,331 deportees, on July 1, 1950 that number was 45,299. See: the USSR MGB report about the work among deportees, ibid., f. 9479, op. 1, d. 641, 1. 367; between October 
colaborators, etc.) were released as 'groundlessly exiled' (in January-September 1949 their number was 163). Additionally about a thousand were in detention or died in the camps. The deported population increased with the birth of about 2,000 children. After the term of incarceration many people were also sent into exile to join their families. Deportees from Lithuania, Latvia and Estonia were treated in the records indiscriminately without any further categorization.

Exiled people did their best to survive, and in the first place they attempted to flee to Lithuania. The escapees as well as the dead modified the statistics of deportation. In 1945-1952 about 5,000 Lithuanians managed to escape from exile. However, in 1945-1948 alone from the total number of 1,722 escapees 1,070 were detained; 470 were returned back to deportation places and 600 were sent to camps.

With the start of mass deportations in 1948 the Soviet government introduced new regulations still further restricting the rights of the deportees: On Deportation, Compulsory and Special Settlement (February 21, 1948); On Compulsory Settlement ((November 24); orders of MVD and MGB: the MVD order no. 00246 (March 8, 1948); the MVD order no. 001145 (December 7) and the MGB order no. 00552 (November 16, 1950). ${ }^{39}$ The freedom of the deportees was restricted in the following ways:

(1) they had no right to leave the place of confinement without the permission of the MVD;

(2) special marks were made by the militia in their passports to limit their movements (within the boundaries of the deportation region); at one time passports were withdrawn and issued again only in 1955; (3) once in a month they had to report to the MVD commandant headquarters, which could require more frequent reports depending on the 'dangerousness' of the deportee, his/her employment and residence; the commandants themselves or their warders had to check all the grown-up deportees at their place of residence

(4) according to the decree of the USSR Supreme Soviet of 25 November 1948 On Penal Amenability for the Escape from Exile a caught escapee was sentenced to 20 years of hard labour (officially this decree applied only to the Chechens, Germans, Crimean Tartars and other nationals, deported during the war, but later its application was also extended to the Lithuanians, Latvians, Estonians and Ukrainians);

1951 and January 1952, 22,113 people were deported from Lithuania (among them 8,339 women and 6,913 children), and the report of 1 January 1953 records only 18,104 Lithuanians, ibid., d. 624, 1. 6; d. 641, 1. 11.

${ }^{39}$ Ibid., d. 836, 1. 215. 
(5) by the decree of the USSR Council of Ministers of 3 June 1948 a deportee could be imprisoned for 'evading job placement'. ${ }^{40}$

The head of each deportee family had the so-called 'family registration card' with the names of all the members of the family, irrespective of their age. Children, born in exile, were also registered. After reaching the age of 16, they were enrolled as grown-up deportees. Having attained their majority and being born in mixed families (of a deportee and a non-deportee), they could, at least theoretically, avoid the fate of their exiled parent by choosing the nationality of the non-deportee (e.g., Russian). However, even this small possibility, rarely practiced by Lithuanians, was ruled out on 16 February 1953.

It is noteworthy that according to the Penal Code the Russians were treated differently from Lithuanians, Germans, Ukrainians and other nationalities even in the case of an attempt to flee from exile. People, sheltering Lithuanian deportees and their children, could be sentenced to five-year gulag confinement, i.e., the sentence was the same as for hiding a member of resistance.

The establishment of a particular legal status of Lithuanian (and other 'unreliable' national) deportees, considerable obstacles regarding their return to the homeland and the fact that a third of the deportation victims were children show that the extermination of the Lithuanian population was directed primarily against ethnic Lithuanians. According to incomplete data 3,500 more people died in exile in 1953-1958 (documentarily attested are only 1,773 deaths; however, there are no data about the mortality in the years 1953 , 1955 and 1958). Deaths occurred continuously, therefore it is important to establish the dynamics of the numbers of deportees up to the end of their confinement. In 1954-1955 the process of releasing Lithuanian deportees was very slow: 735 released in 1954, 1,779 - in $1955,15,879$ - in $1956 .{ }^{41}$ When the USSR Procurator-General R. Rudenko and the Minister of Internal Affairs S. Kruglov planned a release of the deportees, aged 55-60, terminally ill and disabled, they made an 'exception' for the Lithuanians. Together with Western Ukrainians $^{42}$ they had to remain in exile - 'for the sake of public security'. ${ }^{43}$ In 1953 Lithuanians made up only 3.5 per cent of all the

${ }^{40}$ Ibid., 215-216.

${ }^{41}$ Ibid., f. 9479, op. 1, d. 900, 1. 178; a report about Lithuanian deportees, struck off the register in 1955-1956, ibid., d. 919, 1. 64.

${ }^{42}$ In the document they are referred to as OUNs (Organizaciya $U$ krainskikh Nacionalistiv - Ukr.), members of the Organization of Ukrainian Nationalists.

${ }^{43}$ Letter of September 1954, ibid., d. 836, 1. 192. 
deportees of the USSR, while in 1957 that percentage was 29.2. On 1 July 1957 the number of grown-up Lithuanian deportees was $54,866 .{ }^{44}$

The damage done to the Lithuanian nation in the form of Soviet genocidal deportations is equal to the extermination of prisoners in death camps. Of 132,000 people, sent to 'permanent' exile, as many as 28,000 died of diseases, starvation and exhausting labour. It was only in December 1963 that the last several thousand Lithuanian deportees were released. However, for a long time about 50,000 were not allowed to go to their homeland and many of them never came back.

\section{Consequences}

When the former deportees and political prisoners returned home, they found that they were banned from many occupations: jobs in the merchant navy and in about 70 industrial enterprises and organizations. Trips abroad were almost totally forbidden for them. The KGB used to resort to such actions as 'compromise and moral and political isolation' of former deportees and prisoners. It must also be taken into account that their former property was not returned to them. By 1988 the displacement of 3,998 families (12,342 persons) had been identified as unjustified. Before the restoration of Lithuania's independence only nine per cent of the deportees had a right (at least formally) to some part of their former property; there are no data about how much was actually returned. Political prisoners, however, were denied even a theoretical right to recover some part of their property.

The estimates of the losses of the Lithuanian population (and of the Lithuanian nation in particular) are based on archival documents. It must also be borne in mind that due to various inaccuracies, reservations and manipulations in the records themselves, the data, brought forward in this paper, might be insufficiently exact and incomplete.

Nevertheless, it is certain that no less than 456,000 people (every third grown-up Lithuanian; the Lithuanians made up 93 per cent of the political prisoners and 96 per cent of the deportees) were victims of Soviet atrocity and terror or of some form of violence. About 350,000 people were imprisoned, deported, sent to gulags or killed in Lithuania.

The most usual genocide actions were the killings in military punitive operations and campaigns of agents and commandos; physical and moral damage, conscious worsening of living conditions,

${ }^{44}$ Ibid., d. $641,1.10$; d. 900 , 1. 185; d. 949 , 1. 6, 10; d. $976,1.192$. 
leading to a partial extermination of the population in prisons, labour camps and exile, etc. All these methods were corroborated by corresponding orders and plans, justified ideologically or practically ('public security' and other reasons) and put into practice by the supreme Soviet authorities and their subordinate institutions. Genocide and terror as integral parts of Sovietization resulted in the destruction not only of separate individuals, but of entire social layers with their culture, wealth and their social impact. The disastrous losses, sustained by the Lithuanian nation in the course of several decades, have been adversely affecting the further social development of the country. 